\title{
ОСНОВНЫЕ НАПРАВЛЕНИЯ РАЗВИТИЯ ОТЕЧЕСТВЕННОГО ШКОЛЬНОГО ЭКОЛОГИЧЕСКОГО ОБРАЗОВАНИЯ В КОНЦЕ XX - НАЧАЛЕ XXI ВВ.
}

\section{THE MAIN DIRECTIONS OF DEVELOPMENT OF DOMESTIC SCHOOL ENVIRONMENTAL EDUCATION IN THE LATE XX - EARLY XXI CENTURIES V. Avetisyan}

Summary: The school education system in post-Soviet Russia is undergoing major changes and innovations. This article discusses the issue of the formation of environmental education in the national secondary school. The publication is based on regulatory legal acts, opinions of experts on this issue. The given information can be useful to anyone who is interested in the history of the formation of Russian environmental education.

Keywords: environmental education, history of education, school, ecology.

\section{Введение}

$\mathrm{H}$ арастающее с каждым столетием пагубное антропогенное воздействие на природу сегодня приводит нас к мысли, что человечество должно сделать выбор - продолжить истощать природные богатства планеты, загрязнять гидросферу, атмосферу, литосферу или изменить свое отношение к окружающей среде и рационально подходить к использованию ее ресурсов.

Немаловажную роль в обеспечении безопасности окружающей среды играет экологическое образование, формирование которого целесообразно начинать со школьной скамьи. Говоря о школьном экологическом образовании, стоит отметить, что несмотря на наличие учебной литературы, экология как отдельный предмет достаточно долго отсутствовала в школьной программе. Лишь с распадом СССР в общественных кругах вернулись к идее о ее значимости в школьной программе. Стала издаваться полноценная школьная учебная литература, а сама «Экология» становится самостоятельной дисциплиной.

\section{Российское школьное экологическое образование в 1990-х гт.}

Распад СССР привел к серьезным изменениям в системе общественно-политической жизни страны. Изме-

\author{
Аветисян Владимир Рудольфович \\ к.и.н., дочент, ФГБОУ ВО «Самарский государственный \\ сочиально-педагогический университет» \\ vladimir.avetisyan26@mail.ru
}

Аннотация: Система школьного образования в постсоветской России претерпевает серьезные изменения и нововведения. В данной статье рассматривается вопрос становления экологического образования в отечественной общеобразовательной школе. В основу публикации легли нормативно-правовые акты, мнения специалистов по данной проблематике. Приведенные сведения могут быть полезны всем, кто интересуется историей становления российского экологического образования.

Ключевые слова: экологическое образование, история образования, школа, экология.

нения затронули и образовательную систему, которая стала пониматься как функция культуры. Осуществлялся отход от идеологизации образования. В центр самого учебного процесса был поставлен ученик. Вместе с тем акцентировалось внимание на развитии личности учащегося, формировании его мотивационной сферы и независимого мышления [12; С.329].

На рубеже 1980-1990-х гг. экология как наука приобрела особую актуальность. Она стала рассматриваться как область знаний, интегрирующая достижения не только биологии, но и других наук. Экологическое образование получило новый импульс в своем развитии. Построение его системы базировалось на ряде методологических принципов, сформулированных еще в 1980х гг. С.Н. Глазачевым, А.Н. Захлебным, И.Д. Зверевым, И.Н. Пономаревой и др.

Закон РСФСР от 19 декабря 1991 г. «Об охране окружающей природной среды» [2] определил необходимость формирования всеобщего, комплексного и непрерывного экологического воспитания и образования, охватывающего все этапы дошкольного, школьного, внешкольного образования, профессиональную подготовку специалистов в средних и высших учебных заведениях, повышение квалификации кадров.

Особую роль в развитии школьного экологического 
образования начала 1990-х гг. сыграл конкурс на разработку проектов концепции отечественного школьного биологического образования. Были разработаны и предложены две концепции. В первом проекте (разработанным академиком АПН СССР И.Д. Зверевым, профессором РГПУ И.Н. Пономаревой, профессором МГПУ Н.М. Черновым и др.) обосновывалась значимость биологического образования, а в качестве ее цели указывалась подготовка биологически и экологически грамотной личности [13; С.19]. Она должна обладать экологическим и эволюционным стилем мышления, экологической культурой [1; С.32]. Для учащихся 10-11 классов в качестве отдельного блока предлагалось изучение основ экологии. Второй проект концепции был подготовлен коллективом ученых под руководством биолога и методиста Б.Д. Комиссарова [5]. Данная концепция в системе образования также исходила из принципов биологизации и экологизации. Стоит отметить, что большая часть авторского коллектива также принимали участие в разработке первого проекта концепции.

Таким образом, в 1990-е гг. экологическое образование стало одним из приоритетных направлений работы в российских школах. В учебных программах размещались специальные экологические темы. Параллельно с этим в федеральную и региональную части учебного плана стали вводится специализированные предметы экологической направленности.

Особого внимания заслуживает принятый 10 июля 1992 г. закон РФ «Об образовании» [3], согласно которому обязательным стало лишь основное общее образование. На его основе годом позднее был издан Базисный учебный план общеобразовательных учреждений Российской Федерации. Он допускал, что каждая школа может сформировать свой набор естественнонаучных дисциплин и определять количество часов на их изучение [13; С.29]. Среди прочих естественных дисциплин, предлагаемых для изучения, значилась и экология.

Параллельно с этим экологические знания содержались и в других школьных дисциплинах. К примеру, на уроках биологии учащиеся 10 классов изучали основы экологии, на которую отводилось 8 часов.

В начале 1990-х гг. стали открываться образовательные учреждения нового типа - гимназии, лицеи и т.д. Разрабатывается большое количество автономных программ и учебных планов, которые то увеличивали, то уменьшали сведения биоэкологического содержания [12; С.340]. С целью недопущения разрозненности в системе общего образования в 1993 г. впервые был создан проект государственного образовательного стандарта общего образования.

Кроме этого, в том же 1993 г. группа ученых под руководством советского и российского эколога
Н.М. Черновой разработала временный государственный образовательный стандарт школьного экологического образования. Основная его идея заключалась в осуществлении экологического образования на всех этапах системы общего школьного образования [6; С.94]. О заинтересованности общественности в развитии экологического образования и просвещения учащихся свидетельствует также то, что в 1993 г. был создан проект Госстандарта по экологическому образованию.

Середина 90-х гг. XX в. стала временем издания полноценных школьных учебников по экологии. Так, например, в 1995 г. в свет вышли учебники «Экология» [18] Е.А. Криксунова, В.В. Пасечника и А.П. Сидорина и «Экология России» [17] под редакцией Б.М. Миркина и Л.Г. Наумовой. В 1996 г. был опубликован подготовленный под редакцией С.В. Алексеева «Практикум по экологии». К концу десятилетия появились подобные учебные пособия для начальных классов.

Несмотря на определенные достижения в развитии школьного экологического образования во второй половине 1990-х гг., наблюдалось постепенное сокращение часов, отведенных на экологию. Как отмечает социолог Т.А. Орешкина это было связано с ослаблением внимания к экологическим проблемам со стороны государства и общества [6; С.94].

\section{Развитие школьного экологического образования в начале 2000-х гт.}

10 января 2002 г. был опубликован Федеральный закон «Об охране окружающей среды», в 71 статье которого отмечалось: «В целях формирования экологической культуры и профессиональной подготовки специалистов в области охраны окружающей среды устанавливается система всеобщего и комплексного экологического образования, включающая в себя общее образование, среднее профессиональное образование, высшее образовании...» [15].

Принятие данного закона открывало новые возможности для укрепления экологии в системе школьных знаний. Через два года для учащихся 10-11 классов был издан учебник А.Т. Зверева «Экология». В начале 2000-х несколько раз был переиздан учебник «Основы экологии», подготовленный под руководством Н.М. Черновой [7]. Под руководством И.Н. Пономаревой разрабатывалась авторская линия учебников по экологии для учащихся общеобразовательных школ, по которым шло параллельно изучение предметов биологии и экологии с 6 по 9 классы.

Стоит также обратить внимание на разработки региональных педагогов и методистов по исследуемой проблематике, среди которых значатся сотрудники Самарского государственного социально-педагогического 
университета. Так, в 1995 г. 3.И. Чердымова и В.М. Астафьев разрабатывают программу и методические основы курса «Экология и общество» [16] для учащихся 1-9 классов; в 2003 г. под руководством Т.М. Носовой издаются «Концептуальные подходы к дошкольному экологическому образованию и воспитанию»; в 2003 г. и в 2004 г. выходят в свет учебные пособия А.А. Семенова для учащихся старших классов «Экология: Краткий курс» [11] и «Полевой практикум по экологии»; в 2005 г. печатается учебное пособие Т.М. Носовой и В.Г. Шведова «Зоологический музей СГСПУ в образовании для устойчивого развития» и др. [4; С.59]

5 марта 2004 г. приказом Минобразования РФ был утвержден федеральный компонент государственных образовательных стандартов начального общего, основного общего и среднего (полного) общего образования. Однако в перечне дисциплин такого предмета как «Экология» не оказалось. Согласно принятому документу, экологические знания вобрали в себя такие дисциплины, как география (раздел «Природопользование и геоэкология», «География России»), биология (раздел «Взаимосвязи организмов и окружающей среды», «Экосистемы») [8].

Однако, несмотря на то что экология не предполагалась к изучению как самостоятельный предмет некоторые учителя, понимая значимость экологического образования и просвещения вносили в учебный план самостоятельные курсы экологической направленности.

В 2008 г. Президент РФ Д.А. Медведев подписал указ «О некоторых мерах по повышению энергетической и экологической эффективности российской экономики», который предполагал рассмотрение вопроса о включении в федеральные государственные образовательные стандарты основного общего образования основ экологических знаний [14]. Подписание данного документа позволило внимательнее отнестись к экологическому образованию среди молодежи. Условно его можно подразделить на несколько этапов.

Сведения экологического содержания начинали формировать в дошкольном возрасте. Основы бережного отношения к природе, внимание к окружающему миру, любовь ко всему живому закладываются именно в 4-6 лет. Дети с большим удовольствием воспринимают основы экологических знаний, особенно если материал подается наглядно, если можно общаться с живыми существами, ухаживать и заботиться о них. Экологическое воспитание в детском саду происходит во время игр, прогулок и занятий.

В начальных классах происходит закрепление и развитие знаний об окружающей природной и социальной среде, полученных школьником в семье и в дошкольном учреждении. На этом этапе закладываются основы эко- логической культуры, целостного представления о природе.

В средних и старших классах при изучении дисциплины «Биология» рассматриваются такие темы, как «Здоровье и окружающая среда», «Биосфера и человек», «Основы экологии», «Экология человека», «Природа и культура», «Охрана окружающей среды». Кроме этого, закрепляется и совершенствуется нравственная составляющая отношений школьника с окружающей средой.

В государственном образовательном стандарте основного общего образования от 17 декабря 2010 г. [9] мы также не находим экологию в качестве самостоятельной учебной дисциплины. Однако согласно принятому 17 мая 2012 г. ФГОС СОО [10] экология допускалась к изучению в качестве отдельного предмета по выбору учащихся.

\section{К вопросу о перспективах современного школьного экологического образования}

Исследования в последнее десятилетие XX в. позволили выяснить особенности развития экологической культуры, экологической ответственности и экологического сознания, различных видов экологического отношения личности (например, эмоционально-ценностного, субъектноэтического и др.) и механизмов их формирования, что открывало возможность установить четкое соответствие педагогического процесса экологического образования психологическому процессу формирования обозначенных личностных характеристик.

Экологическое образование должно опираться на идеи коэволюции природы и общества, устойчивого развития биосферы; должно быть направлено на преодоление сложившихся в обществе стереотипов посредством формирования духовно-нравственной, экологически грамотной личности и создания условий для ее развития; должно быть нацелено на будущее, стать фактором социальной стабильности.

Современные представления о вариативном образовании в школе хорошо соотносятся с преподаванием экологии - относительно нового предмета: это обстоятельство требуют от самого учителя и от его ученика творческого отношения к обучению, главным результатом которого должно стать воспитание ответственности человека перед природой.

Кроме этого, государство поддерживает дополнительное экологическое образование, которое осуществляется детскими экологическими организациями, детскими домами творчества, экологическими центрами, музеями, библиотеками, экологическими кружками, станциями юных натуралистов через различные формы работы, в том числе экологические лагеря, экологиче- 
ские экспедиции для детей и подростков.

В Законе РФ «Об охране окружающей среды» говорится о том, что руководители организаций и специалисты, ответственные за принятие решений при осуществлении хозяйственной и иной деятельности, которая оказывает или может оказать негативное воздействие на окружающую среду, должны иметь подготовку в области охраны окружающей среды и экологической безопасности.

В целях формирования в обществе экологической культуры, воспитания бережного отношения к природе, рационального использования природных ресурсов осуществляется и экологическое просвещение посредством распространения знаний об экологической безопасности, информации о состоянии окружающей среды и об использовании природных ресурсов.

\section{Зак^ючение}

На основе приведенных сведений следует, что в конце XX - начале XXI вв. отношение к экологическому образованию в системе отечественного общешкольного образования был неоднозначным. Если с распадом СССР экологии уделялось особое внимание, то уже к концу 1990-х гг. знания экологического содержания оставались лишь в других предметах. В начале XXI столетия, экологию как самостоятельную дисциплину также будут поочередно включать или исключать из школьного курса. Несмотря на это экологические знания так или иначе будут содержаться в других предметах, способствуя не только совершенствованию знаний об основных способах защиты природы, но и формируя у учащихся нравственное, уважительное отношение к окружающей среде. Развивая такие чувства, как патриотизм и гражданственность.

\section{ЛИТЕРАТУРА}

1. Биологическое образование в средней школе РСФСР // Биология в школе. - 1991. - № 4. - С. 32-42.

2. Закон РСФСР от 19.12.1991 г. N 2060-І «06 охране окружающей природной среды» // [Электронный ресурс] https://base.garant.ru/6256987/ (Дата 0бращения: 07.09.2021)

3. Закон РФ «06 образовании» от 10.07.1992 N 3266-1 // [Электронный ресурс] http://www.consultant.ru/document/cons_doc_LAW_1888/ (дата 0бращения: 07.09.2021).

4. Краткий курс истории экологии: учебное пособие для студентов, обучающихся по биологическим и экологическим направлениям подготовки / сост. В.Р. Аветисян. - Самара: СГСПУ, 2020. - 80 с.

5. Комиссаров Б.Д. Методологические проблемы школьного биологического образования. - М.: Просвещение, 1991. - 158 с.

6. Орешкина Т.А. Экологическое образование и образование для устойчивого развития в российской школе: настоящее и будущее // Вестник института социологии. - 2017. - № 4. - Т. 8. - С. 91-112.

7. Основы экологии. 10 (11) класс / Н.М. Чернова, В.М. Галушин, В.М. Константинов. - Учебник. — 6-е изд., стереотип. - М.: Дрофа, 2002. - 304 с.

8. Приказ Минобразования РФ от 5.03.2004 г. N 1089 «06 утверждении федерального компонента государственных образовательных стандартов начального общего, основного общего и среднего (полного) общего образования» // [Электронный ресурc] https://base.garant.ru/6150599/ (дата 0бращения: 20.09.2021)

9. Приказ Минобрнауки России от 17.12.2010 N 1897 «0б утверждении федерального государственного образовательного стандарта основного общего образования» // [Электронный ресурc] https://www.garant.ru/products/ipo/prime/doc/55070507/ (дата обращения: 19.09.2021)

10. Приказ Министерства образования и науки РФ от 17.05.2012 г. N 413 «0б утверждении федерального государственного образовательного стандарта среднего общего образования» // [Электронный ресурс] https://base.garant.ru/70188902/ (дата обращения: 19.09.2021)

11. Семенов А.А. Экология. Краткий курс: учебное пособие для учащихся старших классов. - 2-е изд., перераб. и дополн. - Самара: Изд-во СГПУ, 2003. $129 \mathrm{c}$.

12. Семенов А.А., Сайто Х. Становление и развитие школьного биологического образования в современной России // Самарский научный вестник. - 2018. T. 7. - № 3 (24). - С. 339-343.

13. Суматохин С.В. Биологическое образование на рубеже XX-XXI веков: Монография. - М.: Школьная Пресса, 2021. - 416 c.

14. Указ Президента Российской Федерации от 04.06 .2008 г. № 889 «0 некоторых мерах по повышению энергетической и экологической эффективности российской экономики» // [Электронный ресурс] https://rg.ru/2008/06/07/ukaz-dok.html (дата обращения: 21.09.2021).

15. Федеральный закон от 10.01.2002 №7-Ф3 «06 охране окружающей среды»// [Электронный ресурc] http://www.consultant.ru/document/cons_doc_LAW_ 34823/1ebe1ae0326a8d353аaса601eе8fb927f82dc79d/ (дата обращения: 18.09.2021).

16. Чердымова 3.И., Астафьев В.М., Чердымова Е.И. Структура и содержание курса «Экология и общество» для 1-9 кл. общеобразовательных школ // Экологическое образование в целях устойчивого развития (Экологическое образование - XXI век): тез. докл. Междунар. конф. - Тольятти, 1996. - С. 83-85.

17. Экология России: учеб. для 9-11-х кл. общеобразоват. шк. / Б.М. Миркин, Л.Г. Наумова. - М.: АО «МДС»: Юнисам, 1995. - 231 с.

18. Экология: 9-й класс: учебник для общеобразовательных учебных заведений / сост. Е.А. Криксунов, В.В. Пасечник, А.П. Сидорин. - М.: Изд. дом «Дрофа», 1995. -238 c. 